\title{
Finishing of denim fabrics with ozone in water
}

\begin{abstract}
The wet processing of denim jeans is required to achieve comfortable touch and versatile appearance for the final product. The finishing of denim jeans with ozone offers ecological and economic advantages by decreasing rinsing times, water and energy consumption. Ozone, a selective oxidant with high reduction potential, has proven to decolorize textile effluents and it is especially capable of reacting with indigo. In this study, the effect of ozone on the color change of denim fabrics and on the backstaining of the pocket fabrics was studied. Seven different denim fabrics, dyed with the indigo and mixture of indigo and sulfur dyes, were desized and bio-stoned and thereafter treated with ozone in aqueous medium. The response of the color of the indigo dyed denim fabrics to ozone was stronger in comparison with the fabrics dyed with the mixture of indigo and sulfur dyes. The pocket fabrics backstained during the desizing and bio-stoning and subsequent ozone treatment was able to decrease the backstaining. Ozone was able to bleach the denim jeans and decreased the backstaining without the significant loss of the strength of the fabrics. The combined desizing and enzyme wash followed by the ozone wash is thus a promising finishing treatment for denim jeans.
\end{abstract}

Keywords: ozone, denim, jeans, bio-stoning, indigo, backstaining
Volume 5 Issue 2 - 2019

\author{
Taina Kamppuri,' Shahriare Mahmood ${ }^{2}$ \\ 'Materials Science, Tampere University of Technology, Finland \\ ${ }^{2}$ M.A.S.I Company, Vesannontie 9, Finland
}

Correspondence: Taina Kamppuri, Tampere University of Technology, Materials Science, P.O.Box 589, FI-33I0I Tampere, Finland,Tel +35840849 0909, Email taina.kamppuri@tut.fi

Received: March 31, 2018 | Published: April 03, 2019

\section{Abbreviations: CO, cotton; PES, polyester; EL, elastane}

\section{Introduction}

Traditionally, denim has a white cotton weft and a dyed cotton warp with twill weave. Usually, the warp yarn is ring dyed where the dye is concentrated, as layers, on the surface of the yarn rather than diffused inside of the yarn. This phenomenon is exploited in the different finishing treatments of jeans where the aim is to partially remove the dye from the surfaces of the warp yarns to expose the lighter core of the yarns. In addition, the finishing treatments are used to remove sizing agents and to make the jeans softer and more comfortable. The stone wash with pumice stones is nowadays mostly replaced by the treatment with cellulase enzymes. ${ }^{1}$ During the enzyme treatment, the mechanical action in the washing drum, fabric-fabric friction and slight swelling of the outermost layers of wet cotton fibres increased the accessibility of cotton to enzymes and allowed the removal of dyes and caused desired fading and softening of the denim jeans. ${ }^{2,3}$ In addition to cellulases, laccases have been studied in the finishing of indigo dyed denim fabrics and they were found to degrade indigo both in solution and on denim successfully.,5 It is commonly known that the denim fabrics are prone to be affected by the removed indigo during the desizing and enzyme treatment phase. The removed indigo dye is redeposited on the fabric which diminishes the look of the fabric, and is known as backstaining. ${ }^{6-8}$

Ozone is an unstable gas and when transferred into water it can react with a target substance direct or indirect. In the indirect pathway, a promoter catalyzes the degradation of ozone into radicals. If such promoters are not present, ozone oxidizes the target molecules directly. Under acidic conditions $(\mathrm{pH}<4)$ the direct reaction pathway dominates and under basic conditions $(\mathrm{pH}>10)$ the dominating reaction mechanism is the indirect pathway. ${ }^{9,10}$ However, it is usually difficult to accurately determine the oxidation pathway when assessing the ozonation process. ${ }^{11}$ Molecular ozone is a selective oxidant with reduction potential of $2.07 \mathrm{~V}$ at $25^{\circ} \mathrm{C}$. The reduction potential of ozone is higher in comparison with typically used oxidizers, hydrogen peroxide (1.78V) and sodium hypochlorite (1.63V). Ozone oxidizes effectively organic compounds in water and thus, it is used in the cleaning of wastewater and drinking water. ${ }^{9}$ In addition, ozone rapidly and stoichiometrically decolorizes indigo in aqueous acidic solution. ${ }^{12,13}$ The phenomenon is exploited in the methods of determining the amount of ozone in aqueous systems ${ }^{12}$ as well as in the atmosphere. ${ }^{13-15}$ In acidic aqueous solution ozone cleaves the carbon-carbon double bond of sulfonated indigo and produces isatin sulfonate and isatoic disulfonate..$^{12-14}$

Additionally, ozone is very effective in decolorizing textile effluents because it readily oxidizes the dye molecules. Oxidation of dye molecules proceeded typically through the molecular action of ozone without a significant reduction in organic carbon. ${ }^{16-21}$ This indicates that ozone cleaves the chromophore of the dye molecule but does not attack on the intermediates. On the other hand, in the advanced oxidation process, where the formation of radicals from ozone is catalyzed with $\mathrm{H}_{2} \mathrm{O}_{2}$ and UV irradiation, the organic carbon was reduced together with the decolorization of the dyeing effluents..$^{19,22-25}$ In case of vat dyes, the ozonation of textile wastewater has been studied with indigo carmine as the model pollutant ${ }^{21}$ and actual textile effluent from a Malaysian plant using vat dyes. ${ }^{17}$ The studies agreed that the dyes were degraded mainly by the direct action of ozone. The direct reaction favors the cleavage of the carbon-carbon double bond of the indigo molecule, thus producing isatin. Further ozonation of isatin was not detected. ${ }^{21}$

In addition to waste water cleaning, ozone has been studied in the rinsing process of cotton fabric after dyeing with reactive dyes ${ }^{26}$ and in the bleaching of greige cotton fabrics. ${ }^{27,28}$ Additionally, the oxidation capacity of ozone in the finishing of indigo dyed denim jeans ${ }^{29}$ and reactive dyed cotton fabric ${ }^{30}$ has been studied. In both studies, the ozone gas was injected in a closed drum and the ozone treatment was carried out in gaseous environment. The fabrics were moistened before the treatment. Both studies agreed that the treatment time was the most critical parameter that had effect on the color fading. Hmida $\&$ Ladhari ${ }^{29}$ reported that the increased moisture content of the treated fabrics (from 10 to $60 \%$ ) increased the lightness of the ozone treated 
fabrics. They explained that the water caused the slight swelling of the fabric surface and thus increased the available surface for ozone gas.

The wet processing of denim jeans requires considerable amount water, chemicals and energy. The finishing of denim jeans with ozone offers ecological and economic advantages by decreasing rinsing times, water and energy consumption. We studied the wet ozone process in the finishing of denim fabrics. In the system, ozone was dissolved in water and the denim fabrics were ozonized in aqueous environment. The wet ozone technology offers even treatment condition where the variation in the moisture content of fabrics is eliminated. The wet ozone processing combined with the bio-stoning eliminates rinsing steps and enhances the effect of bio-stoning by removing detached dye molecules. The objective was to study the evolution of the color of the denim fabrics during the process steps and the effect of ozone on the backstaining of the initially white pocket fabric. The effect of ozone on the tensile strength of the denim fabrics is also discussed.

\section{Materials and methods}

\section{Fabrics}

The denim fabrics were commercially available denim fabrics from M.A.S.I Company's reserve (Finland) and their properties are listed in Table 1. The square weight was measured according to ISO 3801 (Determination of mass per unit length and mass per unit area). The amount of different materials in warp yarns was determined according to ISO1833 (Quantitative chemical analysis of binary fibre mixtures). The warp yarns were separated from the fabric by hand. Thereafter, the oven dried warp yarns were treated with $75 \% \mathrm{H}_{2} \mathrm{SO}_{4}$ at $50^{\circ} \mathrm{C}$ for $1 \mathrm{~h}$. At these conditions, cotton is totally hydrolyzed. The residual solid material, if present, was filtrated, washed and dried in oven at $105^{\circ} \mathrm{C}$. The penetration of the dye was studied from the cross sections of the warp yarns with an optical microscope (Leitz Laborlux D).

Table I Fabrics and their properties

\begin{tabular}{|c|c|c|c|c|}
\hline Sample & $\begin{array}{l}\text { Dye as given by the } \\
\text { manufacturer }\end{array}$ & Shade & $\begin{array}{l}\text { Composition as given by the } \\
\text { manufacturer* }\end{array}$ & $\begin{array}{l}\text { Square weight, } \\
\mathrm{g} / \mathrm{m}^{2}\end{array}$ \\
\hline & & & $90 \%$ CO & \\
\hline \multirow[t]{3}{*}{ Fabric I } & Indigo & Mid/light indigo blue & $6 \%$ PES & 345 \\
\hline & & & $4 \% \mathrm{EL}$ & \\
\hline & & & $87 \% \mathrm{CO}$ & \\
\hline \multirow[t]{3}{*}{ Fabric 2} & Indigo & Mid indigo blue & $9 \%$ PES & 335 \\
\hline & & & $4 \% \mathrm{EL}$ & \\
\hline & & & $94 \%$ CO & \\
\hline \multirow[t]{3}{*}{ Fabric 3} & Indigo & Mid indigo blue & $4 \%$ PES & 365 \\
\hline & & & $2 \% \mathrm{EL}$ & \\
\hline & & & $91.5 \%$ CO & \\
\hline \multirow[t]{3}{*}{ Fabric 4} & Indigo & Darkest blue & $6 \%$ PES & 330 \\
\hline & & & $2.5 \% \mathrm{EL}$ & \\
\hline & & & $91.5 \%$ CO & \\
\hline \multirow[t]{3}{*}{ Fabric 5} & Indigo & Indigo blue & $6 \%$ PES & 330 \\
\hline & & & $2.5 \% \mathrm{EL}$ & \\
\hline & & & $94 \%$ CO & \\
\hline \multirow[t]{3}{*}{ Fabric 6} & Indigo/sulfur & Blackish blue & $4 \% \mathrm{PES}$ & 300 \\
\hline & & & $2 \% \mathrm{EL}$ & \\
\hline & & & $89.1 \%$ CO & \\
\hline \multirow[t]{2}{*}{ Fabric 7} & Indigo/sulfur & Indigo blue & 8.4\% PES & 300 \\
\hline & & & $2.5 \% \mathrm{EL}$ & \\
\hline \multirow[b]{2}{*}{ Fabric 8} & & & $98 \%$ CO & \\
\hline & Indigo/sulfur & Indigo blue & $2 \% \mathrm{EL}$ & 340 \\
\hline
\end{tabular}

The pocket fabric was white $100 \%$ cotton. The denim fabrics were sewed into leg panels $\left(32 \times 20 \mathrm{~cm}^{2}\right)$ before the washing trials. Inside each leg panel, a piece of the white pocket fabric (about $17 \times 11 \mathrm{~cm}^{2}$ ) was sewed (Figure 1). 


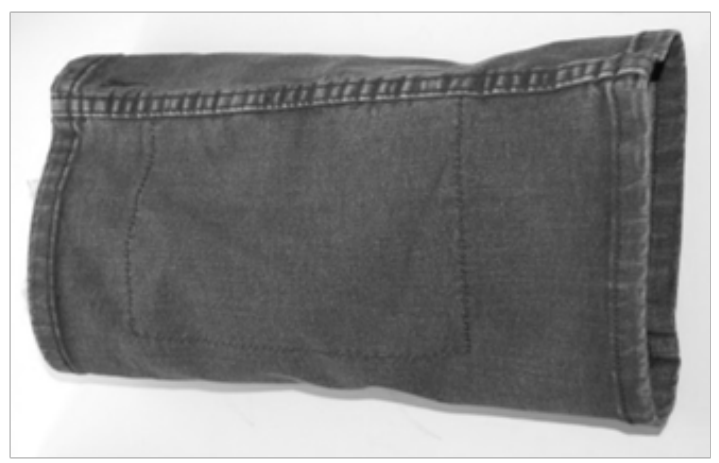

Figure I Leg panel for the washing trials. The stich shows the pocket fabric inside the leg panel.

\section{Washing trials}

All the washing trials were carried out in industrial sampling size ozone wash-extractor equipment (Tonello). For the ozone trials, ozone was generated from oxygen and fed to the washing drum through the ozone dissolving system where ozone gas is dissolved into water. The system has an ozone destroyer and ozone sensors for detecting ozone leakages to avoid health and environmental risks. A combined desizing and bio-stoning was carried out in the same bath with the liquor ratio of 8:1 (dry garments to water), (Figure 2). The desizing was done with alpha-amylase enzyme $(1 \mathrm{~g} / \mathrm{l})$ for 15 minutes at $55^{\circ} \mathrm{C}$ in neutral $\mathrm{pH}$. Thereafter, acetic acid was added to adjust $\mathrm{pH}$ to 5.5 prior to the addition of cellulase enzyme $(0.8 \mathrm{~g} / \mathrm{l})$ for the biostoning process. The enzyme treatment was carried out at $55^{\circ} \mathrm{C}$ for 40 minutes. After rinsing ( 2 minutes with ambient temperature water, $20^{\circ} \mathrm{C}$ ), the enzymes were deactivated by adding alkaline detergent $(1 \mathrm{~g} / 1) . \mathrm{pH}$ was raised over 9 and kept there for 10 minutes at $60^{\circ} \mathrm{C}$ to ensure the deactivation. During the deactivation step, the liquor ratio was $6: 1$. The combined desizing and bio-stoning was ended with cold rinsing followed by tumble drying at $80^{\circ} \mathrm{C}$.

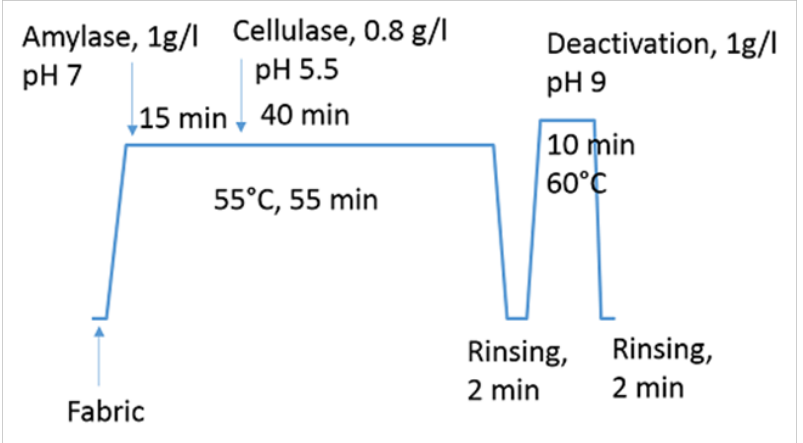

Figure 2 Combined desizing and bio-stoning procedure.

For the trials with ozone, the desizing and bio-stoning step was done exactly the same way as mentioned before without the deactivation. After the first rinsing, $\mathrm{pH}$ was adjusted to $\mathrm{pH} 4.5$ with acetic acid and ozone was injected directly to the liquor, which was circulated continuously to obtain the constant ozone dose (4.6 g ozone/ $\mathrm{kg}$ fabric) for the step. The ozone treatment was carried out at ambient temperature water $\left(20^{\circ} \mathrm{C}\right)$ with the liquor ratio of $5: 1$ for 30 minutes, (Figure 3). Thereafter, ozone was neutralized by increasing the temperature to $60^{\circ} \mathrm{C}$ and by adding sodium metabisulphite $\left(\mathrm{Na}_{2} \mathrm{~S}_{2} \mathrm{O}_{5}\right.$, $1.6 \mathrm{~g} / \mathrm{l})$. The ozone step was ended with cold rinsing followed by tumble drying at $80^{\circ} \mathrm{C}$

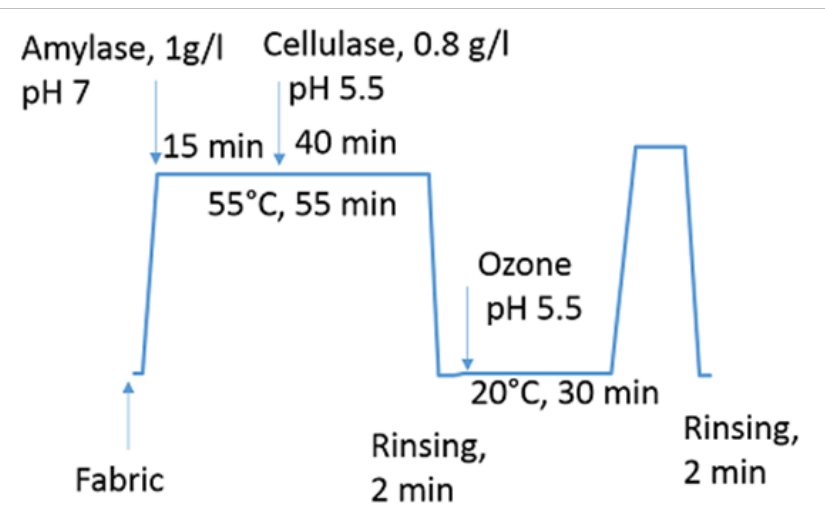

Figure 3 Ozone wash procedure including the combined desizing and biostoning.

\section{Color of the fabrics}

The color properties of the fabrics were measured in the visible region of the spectrum from 400 to $700 \mathrm{~nm}$ with the illuminant D65 and standard observer at $10^{\circ}$ with a Minolta CM1000R spectrophotometer. The colorimetric data $\left(\mathrm{L}^{*}, \mathrm{a}^{*}, \mathrm{~b}^{*}\right.$ values and $\left.\Delta \mathrm{E}\right)$ is given as an average of five measurements. The color difference, $\Delta \mathrm{E}$, was calculated according to Equation 1.

$$
\Delta E=\left[\left(\Delta L^{*}\right)^{2}+\left(\Delta a^{*}\right)^{2}+\left(\Delta b^{*}\right)^{2}\right]^{1 / 2}
$$

\section{Mechanical properties of the fabrics}

The mechanical properties of the fabrics were measured with Testometric M500 machine according to ISO 13934-1 (Tensile properties of fabrics -- Part 1: Determination of maximum force and elongation at maximum force using the strip method) only in the warp direction.

\section{Decolorization of liquid samples}

The spectra of washing baths after the desizing and enzyme step and after the ozone step were recorded from the wavelength range of 300-900nm with a Shimadzu UV-Vis spectrophotometer UV-160A. The water samples were filtrated before the analysis. For the reference indigo (CAS 482-89-3, Acros Organics, the USA) and isatin (CAS 9156-5, Merck KGaA, Germany) were dissolved in DMSO.

\section{Results and discussion}

\section{Fabrics}

The denim fabrics, their composition and square weight are listed in Table 1. Five fabrics were dyed with indigo and three fabrics with the mixture of indigo and sulfur dyes. The fabrics were all woven in twill weave with the dyed warp and white weft. The chemical analysis of the warp yarns confirmed that they were in each fabric made of $100 \%$ cotton. In the microscopy analysis of the warp yarns, there were dark blue fibers in the outer layers of the yarn and less dyed fibers in the inside of the yarn indicating ring dyeing typical of the vat dyed denim (images not shown). The dye in the warp yarns of the Fabric 4 was clearly penetrated deeper into the yarn compared with the other yarns. The dye penetration inside the warp yarns of the Fabrics 7 and 8 was the shallowest. They had the very thin layer of dyed fibers. The penetration of the dye for the rest of the fabrics was quite similar. 


\section{Effect of ozone on color of water samples}

The UV-Vis spectra of water samples collected after the desizing and enzyme step and after the ozone step was recorded to study the effect of ozone on the color of the water samples. For the reference indigo and isatin were dissolved in DMSO and their spectra were recorded as well (Figure 4). The water sample after the enzyme step was clearly blue due to the removed dye particles. However, it did not follow the curve of the reference indigo sample. This is suggested being due to the presence of desizing chemicals in the sample. The water sample after the ozone treatment followed the curve of the reference isatin indicating the degradation of indigo to isatin. ${ }^{21}$ Thus, it was clear that ozone effectively decolorized the water during the ozone step.

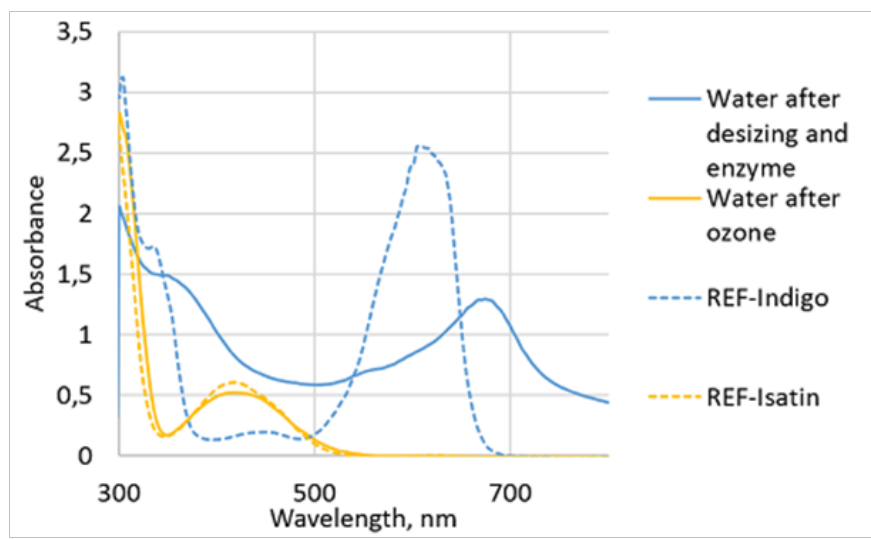

Figure $4 \mathrm{UV}$-Vis spectra of water samples collected after enzyme and ozone steps. For reference indigo and isatin were dissolved in DMSO.

\section{Color of the fabrics}

The color of the denim fabrics was measured from the right side of the leg panels before any treatments and after the combined desizing and enzyme wash and after the ozone treatment. The evolution of the lightness $\left(\mathrm{L}^{*}\right)$ of the denim fabrics during the treatments is shown in Figure 5. During the desizing and enzyme wash, the released dye partially attached back to the fabric which is seen as the decreased lightness value of the desizied and enzyme washed denim samples. This indicates that the enzyme wash made the fabric duller and decreased the contrast between the white weft and dyed warp yarns. It is known that acid cellulases remove indigo effectively. ${ }^{3,6-8}$ In acidic conditions, as in our studies, the redepositing of the removed dyes was explained by the less charged surface of cotton that enhanced the affinity of the negatively charged indigo to cotton and by the adsorption of enzymes with attached indigo on cotton. ${ }^{7,8}$ Additionally, acid cellulases were found to decrease the particle size of agglomerated indigo in water and thus, enhanced the redepositing. ${ }^{8}$

When the ozone step was introduced after the desizing and enzyme wash, the lightness of the denim fabrics was increased near to the original lightness. The lightness of the fabrics dyed with indigo (Fabrics 1-5) was increased in each case slightly compared with the original lightness of the fabrics. However, in case of the fabrics dyed with the mixture of indigo and sulfur dyes (Fabrics 6-8), the lightness after the ozone treatment did not reach the original lightness of the fabrics. It is known that when ozone reacts with complex organic molecules, it favors the cleavage of carbon-carbon double bonds between the aromatic moieties..$^{9,11,31,32}$ Thus, the chemical structure of indigo, two heterocyclic rings joined with the carbon-carbon double bond, is prone to be cleaved by ozone compared with sulfur dyes whose chemical structure is based on sulfur linkages.

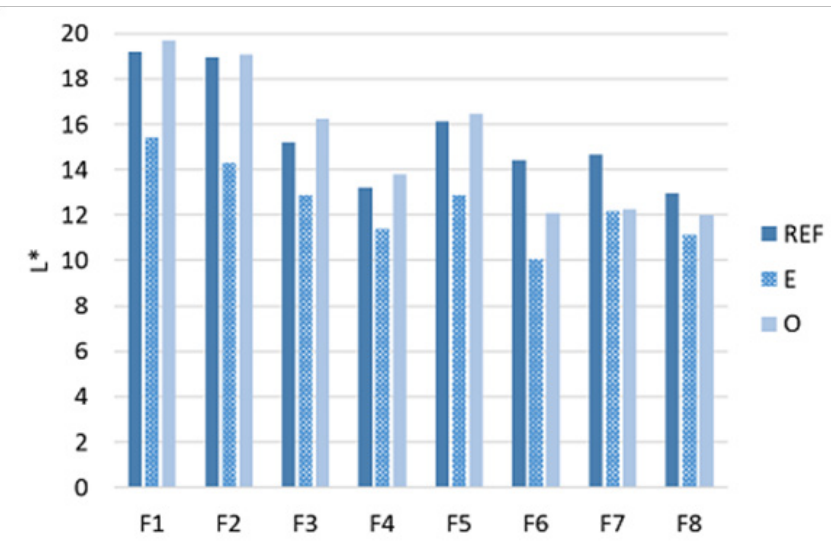

Figure 5 Lightness, L*, of the untreated (RFE), desized and enzyme washed (E) and desized, enzyme washed and ozone $(\mathrm{O})$ treated denim samples.

The color difference of desized and enzyme washed denim fabrics and ozone treated denim fabrics was compared with the color of the untreated denim fabrics. The change in a* component during the different treatments was insignificant. However, the $b^{*}$ component changed clearly and the color difference of the blue component $(\Delta \mathrm{b})$ was calculated (Figure 6). The color difference was the greatest after the combined desizing and enzyme wash. Originally lighter fabrics (especially Fabrics 1,2 and 5) had bigger color change during the combined desizing and enzyme wash indicating that the whiter core of the ring dyed yarns appeared quicker in comparison to the darker fabrics. In addition to decreased lightness, the $-b^{*}$ value decreased during the enzyme wash which is seen as the increased $\Delta b$ value in Figure 6. This indicates that the fabrics turned to more bluish due to the removal of the starch in the desizing step that brightened the blue color. Even the lightness of the samples after the ozone step was nearly the same as of the original denim fabrics, the color did not turn back to the original. This is due to the unchanged $-b^{*}$ value. The color difference of the ozone treated fabrics compared with the enzyme treated fabrics ( $\triangle \mathrm{E} O \mathrm{O}$ vs. $\mathrm{E}$, in Figure 6) can be considered as the response of the fabric to ozone. The fabrics dyed with the mixture of indigo and sulfur dyes (Fabrics 6-8) had the lower response to the ozone compared with fabrics that were dyed with indigo (Fabrics 1-5).

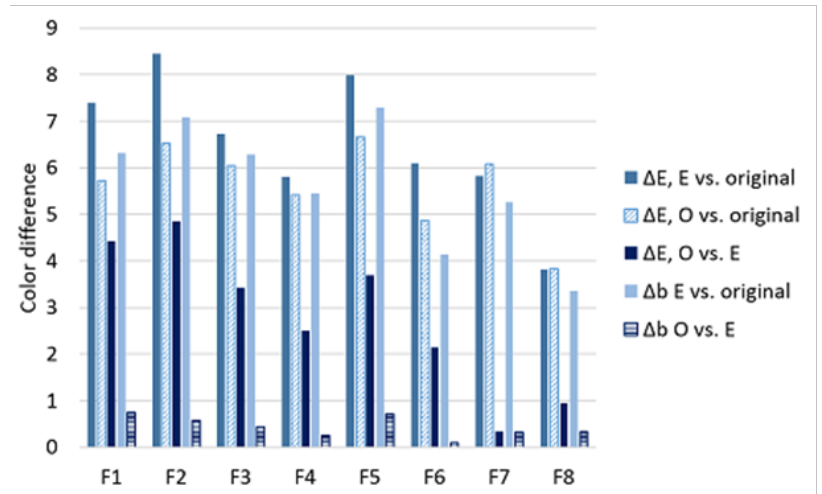

Figure 6 Color difference, $\Delta \mathrm{E}$, and difference in the $\mathrm{b}^{*}$-component, $\Delta \mathrm{b}$, of the fabrics. $E$ vs. REF=color of desized and enzyme washed fabrics compared with untreated fabric. $O$ vs. REF=color of ozone treated fabric compared with untreated fabric. $\mathrm{O}$ vs. $\mathrm{E}=$ color of ozone treated compared with untreated fabric. 
A piece of white pocket fabric was sewed inside each leg panel. The color of the pocket fabric was measured after the desizing and enzyme wash and after the ozone wash and compared with the color of the untreated fabric. The backstaining of the pocket fabric was determined as the color difference between the untreated and differently treated pocket fabrics. The pocket fabric was clearly backstained during the combined desizing and enzyme wash due to the redeposition of removed dye on the pocket fabric. The ozone treatment was able to decrease the color difference of the pocket fabrics indicating the bleaching of the pockets (Figure 7). Those fabrics that had the good response to ozone also had whiter pocket fabric after the ozone treatment logically, (Figure 8).

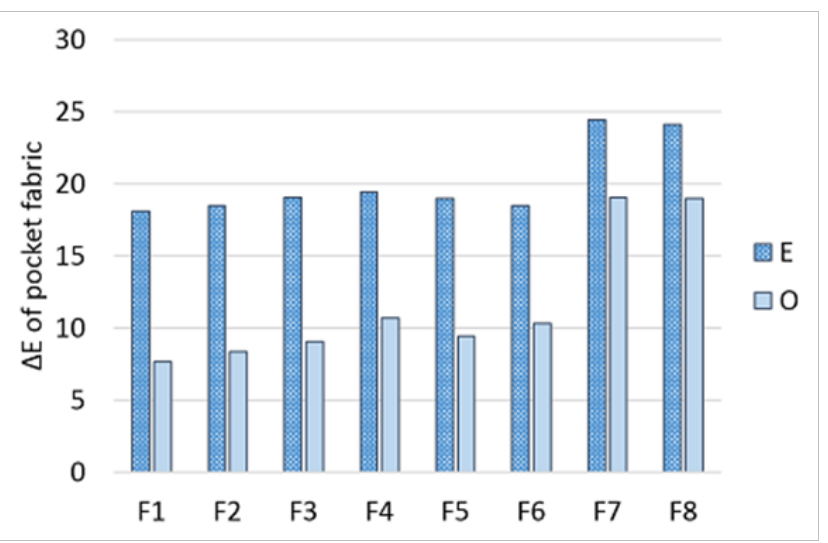

Figure 7 Backstaining of the pocket fabrics i.e. color change $(\Delta \mathrm{E})$ of the pocket fabrics after enzyme, $E$, and ozone, $O$.

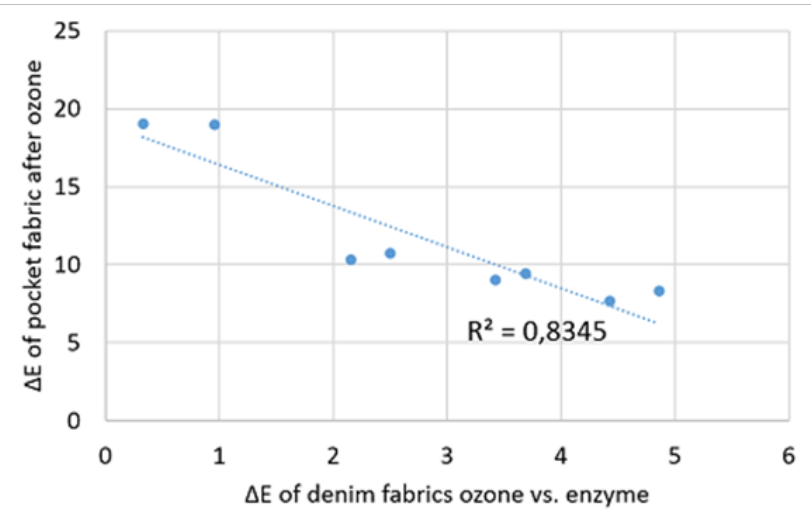

Figure 8 Relationship between backstaining of the pocket fabric after ozone wash ( $\Delta \mathrm{E}$ of pocket fabric after ozone) to the response of the denim fabrics to ozone ( $\Delta \mathrm{E}$ of fabrics ozone vs. enzyme).

\section{Effect of ozone on mechanical properties of fabrics}

The tensile strength of denim fabrics with the high (Fabric 2) and low (Fabric 8) response of color to ozone was measured in the warp direction, (Table 2). Regardless their different response on the color fading by ozone, the effect of ozone on their mechanical properties was at the same level. The strain was slightly increased after the desizing and enzyme step due to the removal of the sizing. The subsequent ozone treatment did not have an effect on the strain at break. The loss of strength of the fabrics was insignificant after the desizing and enzyme step compared with the untreated fabric. The ozone treatment decreased the strength of the Fabric 2 by $7 \%$ and Fabric 8 by $5 \%$. It is known that ozone is able to cleave the glycosylic linkage of cellulose ${ }^{33}$ and thus decrease the molecular weight of cellulose. Additionally, the decreased tensile strength of cotton fabrics after the ozone treatment has been reported. ${ }^{26-29}$

Table 2 Tensile strength and strain at break of denim fabrics. Standard deviation is given in parenthesis

\begin{tabular}{|c|c|c|}
\hline Sample & Force at break, $\mathbf{N}$ & Strain at break, $\%$ \\
\hline \multicolumn{3}{|l|}{ Fabric 2} \\
\hline Untreated & $|24|(47.8)$ & $28.1(0.64)$ \\
\hline Desized and enzyme washed & $1233(42.3)$ & $29.2(0.45)$ \\
\hline Ozone washed & $1142(62.4)$ & $29.1(0.45)$ \\
\hline \multicolumn{3}{|l|}{ Fabric 8} \\
\hline Untreated & $1720(120.2)$ & $22.4(0.50)$ \\
\hline Desized and enzyme washed & $1763(119.6)$ & $29.2(0.73)$ \\
\hline Ozone washed & $1677(43.1)$ & $29.0(0.84)$ \\
\hline
\end{tabular}

\section{Conclusion}

Ozone was able to decolorize the water during the finishing treatment of denim jeans. It clearly cleaved the chromophores of dye molecules and turned initially blue water to yellowish. This is due to the cleavage of the carbon-carbon double bond of the indigo dye molecule that destroyed the chromophore of the molecule and produced yellow isatin.

During the desizing and enzyme wash the lightness of the treated denim fabrics decreased due to the redeposition of released dye that decreased the contrast between dyed warp and undyed white weft. Additionally, the fabrics turn bluer due to the removal of sizing chemicals. Subsequent ozone treatment did not change the blue component of the fabrics, but was able to increase the lightness of the fabrics. The lightness of the fabrics that were dyed with indigo was increased more in comparison with the untreated fabrics. Thus, ozone was able to bleach the fabric. The response of the fabrics dyed with the mixture of indigo and sulfur was lower compared with the indigo dyed fabrics. This was suggested being due to the different chemical structure of the dyes.

The backstaining was measured as the color difference of the treated pocket fabric compared with the untreated white fabric. During the desizing and enzyme wash, the pocket fabric clearly turned blue. The subsequent ozone treatment clearly decreased the color difference and was thus able to bleach the redeposited dye. The color difference of the denim fabrics during the desizing and enzyme wash did not correlate with the backstaining. However, the denim fabrics that showed the good response to the ozone also had lower backstaining after the ozone treatment, logically.

The studies showed that the wet ozone wash, where the ozone is dissolved in water, was able to bleach the denim jeans and decreased the backstaining without the significant loss of the strength of the fabrics. The combined desizing and enzyme wash followed by the ozone wash is thus a promising finishing treatment for denim jeans.

\section{Acknowledgments}

The project was partially financed by The Finnish National Technology Agency (TEKES). The funding from MASI Company and the technical assistance of Maija Järventausta are gratefully acknowledged. 


\section{Conflicts of interest}

Author declares there is no conflict of interest in publishing the article.

\section{References}

1. Tarhan M, Sariisik M. A Comparison among performance characteristics on various denim fading processes. Text Res J. 2009;79(4):301-309.

2. Zeyer C, Rucker JW, Joyce TW, et al. Enzymatic deinking of cellulosic fabric. Text Chem Color. 1994;26(3):26-31.

3. Heikinheimo L. Trichoderma reesei cellulases in processing of cotton. Otamedia, Espoo, Finland: VTT Publications; 2002. 77 p.

4. Campos R, Cavaco-Paulo A, Robra KH, et al. Indigo degradation with laccases from polyporus sp. and sclerotium rolfsii. Text Res $J$. 2001;71(5):420-424.

5. Campos R, Kandelbauer A, Robra KH, et al. Indigo Degradation with Purified Laccases from Trametes hirsuta and Sclerotium rolfsii. $J$ Biotechnol. 2001;89(2-3):131-139.

6. Cavaco-Paulo A, Morgado J, Andreaus J, et al. Indigo backstaining during cellulase washing. Text Res J. 1998;68(6):398-401.

7. Andreaus J, Campos R, Gübitz G, et al. Influence of cellulases on indigo backstaining. Text Res J. 2000;70(7):628-632.

8. Campos R, Cavaco-Paulo A, Andreaus J, et al. Indigo-cellulases interactions. Text Res J. 2000;70(6):532-536.

9. Gottschalk C, Libra JA, Saupe A. Ozonation of water and wastewater A practical guide to understanding ozone and its applications. 2nd ed. Weinheim, Germany: Wiley-VHH Verlag; 2010. 378 p. ISBN: 978-3527-31962-6

10. Chu W, Ma C-W. Quantitative prediction of direct and indirect dye ozonation kinetics. Water Res. 2000;34(12):3153-3160.

11. Von Gunten U. Ozonation of drinking water: Part I. Oxidation kinetics and product formation. Review Water Res. 2003;37(7):1443-1467.

12. Bader H, Hoigne J. Determination of ozone in water by the indigo method. Water Res. 1981;15(4):449-456.

13. Felix EP, Filho JP, Garcia G, et al. A new fluorescence method for determination of ozone in ambient air. Microchem J. 2011;99(2):530534

14. Felix AP, Cardoso AA. Colorimetric determination of ambient ozone using indigo blue droplet. J Braz Chem Soc. 2006;17(2):296-301.

15. Alexy M, Voss G, Heinze J. Optochemical sensor for determining ozone based on novel soluble indigo dyes immobilised in a highly permeable polymeric film. Anal Bioanal Chem. 2005;382(7):1628-1641.

16. Arslan I. Treatability of simulated disperse dye-bath by ferrous iron coagulation, ozonation and ferrous iron-catalyzed ozonation. $J$ Hazard Mater. 2001;85(3):229-241.

17. Ramasamy RK, Rahman NA, San WC. Effect of temperature on the ozonation of textile waste effluent. Color Technol. 2001;117(2):95-97.
18. Szpyrkowicz L, Juzzolino C, Kaul SN. A comparative study on oxidation of disperse dyes by electrochemical process, ozone, hypochlorite and Fenton reagent. Water Res. 2000;35(9):2129-2136.

19. Neamtu M, Yediler A, Siminiceanu I, et al. Decolorization of disperse red 354 azo dye in water by several oxidation processes - a comparative study. Dyes Pigm. 2004;60(1):61-68.

20. Soares OSGP, Orfao JJM, Portela D, et al. Ozonation of textile effluents and dye soluitons under continuous operation: Influence of operating parameters. J Hazard Mater. 2006;137(3):1664-1673.

21. Bernal M, Romero R, Roa G, et al. Ozonation of Indigo carmine catalyzed with Fe-pillared clay. In: VM Monsalvo, editor, efficient management of wastewater from manufacturing new treatment technologies. Oakville, Canada: Apple Academic Press; 2015. 310 p. DOI: 10.1201/b18616-17.

22. Alaton IA, Balcioglu IA, Bahnemann DW. Advanced oxidation of a reactive dyebath effluent: comparison of $\mathrm{O}_{3}, \mathrm{H}_{2} \mathrm{O}_{2} / \mathrm{UV}-\mathrm{C}$ and $\mathrm{TiO}_{2} / \mathrm{UV}-\mathrm{A}$ processes. Water Res. 2002;36(5):1143-1154.

23. Azbar N, Yonar T, Ketioglu K. Comparison of various advanced oxidation processes and chemical treatment methods for COD and color removal from a polyester and acetate fiber dyeing effluent. Chemosphere. 2004;55(1):35-43.

24. Muthukumar M, Sargunamani D, Selvakumar N. Statistical analysis of the effect of aromatic, azo and sulphonic acid groups on decoloration of acid dye effluents using advanced oxidation process. Dyes Pigm. 2005;65(2):151-158.

25. Faouzi M, Canizares P, Gadri A, et al. Advanced oxidation processes for the treatment of wastes polluted with azoic dyes. Electrochim Acta. 2006;52(1):325-331.

26. Mao YH, Guan Y, Luo DH, et al. Investigation of a homogeneous activating ozonation method in the rinsing procedure of cotton fabric dyed with reactive dye. Color Technol. 2011;127(4):256-267.

27. Prabaharan M, Venkata Rao J. Study on ozone bleaching of cotton fabric - process optimization, dyeing and finishing properties. Color Technol. 2001;117(2):98-103.

28. Eren HA, Ozturk D. The evaluation of ozonation as an environmentally friendly alternative for cotton preparation. Text Res J. 2010;81(5):512519 .

29. Hmida SB, Ladhari N. Study of parameters affecting dry and wet ozone bleaching of denim fabric. Ozone-Sci Eng. 2016;38(3):175-180.

30. Kan C, Cheung H, Chan Q. A study of plasma-induced ozone treatment on the colour fading of dyed cotton. J Clean Prod. 2016;112(4):3514 3524.

31. Hoigne J, Bader H. Rate constants of reactions of ozone with organic and inorganic compounds in water. Water Res. 1983;17(2):173-183.

32. Razumovskii SD. Reactions of ozone with aromatic compounds. In: GE Zaikov, editors. Chemical kinetics. Leiden, The Netherlands: CRC Press; 2005. $526 \mathrm{p}$.

33. Lemeune S, Barbe JM, Trichet A, et al. Degradation of cellulose models during an ozone treatment. Ozonation of glucose and cellobiose with oxygen or nitrogen as carrier gas at different pH. Ozone-Sci Eng. 2000;22(5):447-460. 